\title{
Pathogenesis of Mooren's ulcer: some new concepts
}

\author{
P. I. MURRAY AND A. H. S. RAHI \\ From the Department of Pathology, Institute of Ophthalmology, University of London, and \\ Moorfields Eye Hospital, London
}

SUMMARY Mooren's ulcer is a chronic, painful corneal ulceration of unknown aetiology. Recent histological and immunological studies suggest an autoimmune basis. It is now becoming clear that the immune system plays an intricate role in maintaining homoeostasis in health and disease. Regulation of the immune response appears to involve a subset of peripheral blood Tymphocytes known as suppressor cells. A qualitative or quantitative deficiency of suppressor cells may therefore be responsible for chronic inflammation, autoimmune disease, and immunodeficiency states. To explain the reported immunological aberrations the number of suppressor $\mathrm{T}$ cells in addition to other immunological parameters were studied in a patient with bilateral Mooren's ulcers. A deficiency of suppressor $\mathrm{T}$ cells was found in the peripheral blood. This deficit in the immunoregulatory mechanism explains some of the immunological abnormalities reported in previous studies. Furthermore this study provides additional evidence for an autoimmune aetiology. In the light of these findings the possibility of a new line of treatment has been raised.

Mooren's ulcer ${ }^{1}$ is a chronic, painful ulceration of the cornea that begins in the periphery with a steep, undermined, leading edge. The ulcer spreads first circumferentially and then centrally to involve the whole cornea. It is bilateral in approximately $25 \%$ of cases but does not necessarily develop simultaneously in both eyes. An unequivocal cause has not been established for this progressive and relentless condition, but an autoimmune aetiology is strongly suspected.

Inflammation is essentially a protective response to minimise the effect of injuries-microbiological, immunological, or otherwise. In certain individuals the inflammatory response may, however, outlive its useful purpose. Failure to 'switch-off' certain inflammatory responses beyond their purposeful existence represents a weakness in the regulatory mechanism in the immune response involving a subset of peripheral blood lymphocytes, known as suppressor cells. It has been suggested that patients having a qualitative or quantitative deficiency of this suppressor machinery are more prone to chronic inflammation $^{2}$ and autoimmune disease. ${ }^{3}$

Correspondence to Dr P. I. Murray, Department of Pathology, Institute of Ophthalmology, 17-25 Cayton Street, London, ECIV 9AT.
Developments in the field of cellular immunology are now constantly illuminating the complex functions of lymphocytes in humoral and cell-mediated immunity. With the advent of monoclonal antibodies ${ }^{4}$ the role of T-cell subsets, ${ }^{5}$ especially helper and suppressor T-cells, has been made clearer. Imbalances of the helper/suppressor ratio have increased our understanding of immune regulation in various disease processes.

Peripheral blood lymphocytes consist of 3 distinct cell populations:

(1) B lymphocytes number about $20 \%$ of human peripheral blood mononuclear cells. They originate and differentiate in the bone marrow and have immunoglobulins on their surface membrane. These lymphocytes become antibody secreting plasma cells in lymphoid organs and inflamed tissues.

(2) $T$ lymphocytes number $65-70 \%$ of human peripheral blood mononuclear cells. Their precursors are in the bone marrow, but differentiation and maturation takes place in the thymus, where its microenvironment and the hormones produced by epithelial cells play an important role. They do not express surface immunoglobulin but spontaneously form rosettes with sheep red blood cells-known as $E$ rosettes. 
T lymphocytes can be subdivided into at least 4 subsets: (a) Helper T-cells $\left(\mathrm{T}_{\mathrm{H}}\right)$-number $60 \%$ of $\mathrm{T}$ cells. They produce chemical messengers such as interleukin which allow B lymphocytes to transform into plasma cells and influence other $\mathrm{T}$ cell subsets. They can be identified by monoclonal antibody, for example, OKT4 (Ortho Diagnostics).

(b) Suppressor $\mathrm{T}$ cells $\left(\mathrm{T}_{\mathrm{S}}\right)$, number $30 \%$ of $\mathrm{T}$ cells. They have a modulatory role and check overstimulation or prolonged stimulation of the immune system. They can similarly be identified by monoclonal antibody, for example, OKT8.

(c) Cytotoxic $\mathrm{T}$ cells $\left(\mathrm{T}_{\mathrm{C}}\right)$. These cells on antigenic challenge become cytotoxic for virus-infected cells and grafted tissues. They have some features in common with suppressor T-cells.

(d) Delayed hypersensitivity $\mathrm{T}$ cells $\left(\mathrm{T}_{\mathrm{DH}}\right)$. These cells share some membrane characteristics with helper $\mathrm{T}$ cells, and produce inflammatory lymphokines (soluble, low molecular weight proteins) including various chemotactic and permeability factors.

(3) Null lymphocytes (non-B, non-T) number $10 \%$ of human peripheral blood mononuclear cells and represent a heterogenous group. Natural killet (NK) cells can kill target cells in the absence of antibody, but the killer (K) cells always require the presence of IgG. The group probably contains undifferentiated $T$ lymphocytes and monocytes. The NK cells are now believed to play an important role in immune surveillance and control of tumour growth.

Decreased numbers of $T$ lymphocytes (as measured by the number of lymphocytes forming $E$ rosettes with sheep red blood cells) have been observed in patients with various immunodeficiency diseases, sarcoidosis, leprosy, systemic virus infections, collagen vascular disease, and some types of cancer. ${ }^{6}$ It has also been shown that there is an abnormality in $T$ cell subsets (either qualitative or quantitative) in such diseases as systemic lupus erythematosus ${ }^{7}$ (SLE), multiple sclerosis, ${ }^{8}$ myasthenia gravis, ${ }^{9}$ atopic eczema, ${ }^{10}$ and chronic active hepatitis. ${ }^{2}$

Abnormalities in T cells and their subsets have also been reported in various ophthalmological conditions. Char et al. ${ }^{11}$ found a significant decrease in $\mathrm{E}$ rosettes in patients with Vogt-Koyanagi-Harada syndrome, and Heredia et al. ${ }^{12}$ detected reduced suppressor cell activity in retinitis pigmentosa. Grabner et al. ${ }^{13}$ stated that during the active stage of acute anterior uveitis the function of the suppressor cells was abnormal. Nussenblatt et al. ${ }^{14}$ have reported an increase in suppressor cell activity in active posterior uveitis, and in the same condition Nussenblatt $e t$ al. ${ }^{15}$ showed an increased number of suppressor cells. We ourselves have found a reduction in suppressor cells in a case of lepromatous uveitis (unpublished observation). Abnormalities of the helper/suppressor ratio have also been found in patients with Graves' ophthalmopathy, ${ }^{16}$ and recurrent herpes simplex keratitis. ${ }^{17}$

As previous studies ${ }^{18-26}$ have suggested an autoimmune basis for Mooren's ulcer, it was decided therefore to investigate subsets of peripheral $T$ lymphocytes and other immunological parameters in a 67-year-old man suffering from bilateral Mooren's ulcers.

\section{Case report}

A 67-year-old man developed soreness and irritation of his left eye in June 1981. There was no history of injury. On examination his visual acuities were $6 / 5$ right, $6 / 6$ left, and he had a left corneal ulcer involving the inferotemporal periphery. He was initially treated with a topical steroid and antibiotic combination, which had little effect. Over the next few months the ulcer became more painful and progressed relentlessly despite the addition of systemic indomethacin to the above medication. In May 1982 he underwent a left conjunctival resection combined with cryotherapy, but the ulcer advanced progressively, and in December 1982 a left total tarsorrhaphy was performed.

In January 1982 he developed a painful ulcer in the inferotemporal periphery of his right cornea. This initially responded well to a right conjunctival resection and cryotherapy performed in March 1982. Unfortunately his right eye flared up 4 months later, and a further conjunctival resection and cryotherapy were undertaken. In December 1982, after another flare-up, a right conjunctival flap was fashioned in the inferotemporal quadrant. In February 1983 he was admitted for investigation. On admission his right visual acuity was $6 / 5$, his left visual acuity was perception of light only. His medication was guttae Predsol-N (prednisolone and neomycin) 4 times daily to the right eye, indomethacin slow release $75 \mathrm{mg}$ once daily, and propranolol $40 \mathrm{mg}$ twice daily. The last drug was for hypertension, which had been diagnosed 5 years earlier. During his stay in hospital he was found to have diabetes mellitus and was started on glibenclamide $2.5 \mathrm{mg}$ twice daily.

\section{Materials and methods}

MEASUREMENT OF T CELLS (E ROSETTES)

AND THEIR SUBSETS

$15 \mathrm{ml}$ of venous blood collected in a preservative-free heparinised container was mixed with equal quantities of Roswell Park Memorial Institute (RPMI) 1640 tissue-culture medium (Flow laboratories) containing $2 \mathrm{~g} / \mathrm{l}$ sodium bicarbonate. Lymphocytes were isolated by a standard density 
gradient technique by Ficoll-Paque. The lymphocytes obtained were washed 3 times and the number adjusted to $3 \times 10^{9} / 1$. (Mean viability of lymphocytes $>98 \%$ as assessed by $0.1 \%$ trypan blue exclusion.) Two drops of neuraminidase-treated sheep red blood cells, which had been stored in fetal calf serum containing antibiotics, were then added to $200 \mu \mathrm{l}$ of the lymphocyte suspension, and after spinning for 5 minutes at $300 \mathrm{~g}$ this was then incubated at $4^{\circ} \mathrm{C}$ for one hour. The cells were then gently resuspended, and at least $200 \mathrm{E}$ rosettes (lymphocyte with at least 3 red cells attached to it) were counted in a haemocytometer. A total lymphocyte count was also performed.

Subpopulations of $\mathrm{T}$ cells were estimated by indirect fluorescence. Monoclonal antisera recognising helper (OKT4, Ortho Diagnostics) and suppressor (OKT8) subpopulations were used. $5 \mu \mathrm{l}$ of the monoclonal reagents or phosphate buffered saline (PBS) was added to $200 \mu$ l aliquots of lymphocyte suspension. The cells were incubated at $4^{\circ} \mathrm{C}$ for 20 minutes, after which excess antibody was removed by washing twice with cold PBS and sodium azide (to prevent capping). $100 \mu \mathrm{l}$ of a second layer of fluorescein labelled rabbit antimouse Ig was then added to each aliquot and left to incubate for a further 20 minutes at $4^{\circ} \mathrm{C}$. After 2 washes wet slide preparations were made. Positively stained cells were counted under a Zeiss epifluorescence microscope (at least 200 cells were counted per slide), and the results were expressed as a percentage after subtraction for nonspecific staining.

Serum IgG, A, M, rheumatoid factor, and Creactive protein were all measured by rate nephelometry with the Beckman Immunochemistry Analyser II and commercially available human antisera.

Circulating immune complexes (CIC) were precipitated by a polyethylene glycol (PEG) technique. The complexes were then redissolved and analysed for precipitable IgG with the Beckman Immunochemistry Analyser II. The level of IgG in the CIC was expressed as a percentage of the total serum concentration of IgG by the following equation:

$$
\frac{\text { Concentration of } \mathrm{IgG} \text { in } \mathrm{CIC}(\mathrm{mg} / \mathrm{l})}{\text { Serum concentration of } \mathrm{IgG}(\mathrm{mg} / \mathrm{l})} \times 100 \text {. }
$$

Circulating antibodies to cornea, conjunctiva, and nonocular tissues were detected by a standard indirect immunofluorescence technique. Examination was performed as before with a Zeiss epifluorescence microscope equiped with the appropriate interference filters.

The results thus achieved were compared with normal values obtained in this laboratory.

\section{Results}

Table 1 Immunological parameters in a patient with Mooren's ulcer

\begin{tabular}{|c|c|c|}
\hline Immunological parameter & Result & Normal values \\
\hline Total T cells ( $\mathrm{E}$ rosettes) & $65 \%$ & $65-75 \%$ \\
\hline Helper $\mathrm{T}$ cells $(\mathrm{OKT} 4+)$ & 45 & $40-45$ \\
\hline Suppressor T cells (OKT8+) & 13 & $23-27$ \\
\hline $\begin{array}{l}\text { Helper/suppressor ratio } \\
\text { Serum immunoglobulins }\end{array}$ & $3 \cdot 5$ & $1 \cdot 6-1 \cdot 9$ \\
\hline IgG & $11 \cdot 6 \mathrm{~g} / \mathrm{l}$ & $6 \cdot 0-15 \cdot 0 \mathrm{~g} / 1$ \\
\hline $\operatorname{Ig} A$ & $5 \cdot 84 \mathrm{~g} / 1$ & $0 \cdot 9-4 \cdot 0 \mathrm{~g} / 1$ \\
\hline IgM & $1.20 \mathrm{~g} / 1$ & $0 \cdot 6-3 \cdot 0 \mathrm{~g} / 1$ \\
\hline \multicolumn{3}{|l|}{ Circulating autoantibodies to: } \\
\hline Cornea & $\begin{array}{l}\text { Both positive } \\
1: 10 \text { dilution }\end{array}$ & - \\
\hline Conjunctiva & $\begin{array}{l}\text { (rat substrate) } \\
\text { both not } \\
\text { detected on } \\
\text { human substrate }\end{array}$ & - \\
\hline \multicolumn{3}{|l|}{ Antibodies to nonocular tissues: } \\
\hline Antinuclear antibodies & Not detected & $15 \%$ \\
\hline Gastric parietal cells & Not detected & $3 \%$ \\
\hline Smooth muscle & Not detected & $16 \%$ \\
\hline Circulating immune complexes & $0 \cdot 13 \%$ IgG & $<0.7 \%$ IgG \\
\hline Rheumatoid factor & $<60.0 \mathrm{IU} / \mathrm{ml}$ & $<60.0 \mathrm{IU} / \mathrm{ml}$ \\
\hline C-reactive protein & $<6.0 \mathrm{mg} / \mathrm{l}$ & $<6.0 \mathrm{mg} / \mathrm{l}$ \\
\hline
\end{tabular}

Table 2 Immunopathological abnormalities in Mooren's ulcer

1 Infiltration of tissue by lymphocytes/plasma cells/neutrophils eosinophils/mast cells

2 Raised serum $\operatorname{Ig} \mathrm{A}$

3 Tissue fixed immunoglobulins and complement

4 Circulating auto antibodies to cornea and conjunctiva

5 Raised circulating immune complex

6 Cellular immunity to corneal antigen

7 Reduced suppressor T cells

\section{Discussion}

Recent studies indicate that Mooren's ulcer may have an immunological basis. The relevant findings (Table 2) can be discussed under 3 headings:

\section{HISTOLOGICAL EVIDENCE OF AN IMMUNE}

REACTION

Brown ${ }^{18}$ found lymphocytes and plasma cells in conjunctiva adjacent to the ulcer. This was confirmed by Foster et al. ${ }^{19}$ who also noted the presence of neutrophils. Tabbara and Ostler, ${ }^{20}$ as well as finding the above 3 cell types, showed that $15-20 \%$ of the infiltrating cells in the conjunctiva were eosinophils. Review of cases on the registry of this department showed in addition the presence of degenerate mast cells.

\section{NON-SPECIFIC IMMUNOLOGICAL PARAMETERS}

Mondino et al. ${ }^{21}$ revealed that $56 \%$ of patients with Mooren's ulcer had elevations of serum IgA which 
were 2 standard deviations above the mean for normal persons. (Mondino ${ }^{22}$ reported that by continuing this study the figure had risen to $63 \%$.) High levels of serum $\operatorname{IgA}$ was also an important feature in this case. The reason for this immunological abnormality is obscure. It is of interest that raised serum IgA levels have also been reported in patients with acute anterior uveitis associated with active ankylosing spondylitis. ${ }^{27}$ They also found deposition of immunoglobulins $G$ and $M$ and complement in conjunctiva adjacent to the ulcer. This finding has since been confirmed by Foster et al. ${ }^{19}$ and Tabbara and Ostler. ${ }^{20}$ Berkowitz et al. ${ }^{23}$ found circulating immune complexes at higher levels in patients with Mooren's ulcer than in the normal population. Using a PEG precipitation technique, however, we failed to confirm this finding.

\section{SPECIFIC (CORNEAL AND CONJUNCTIVAL) IMMUNE PARAMETERS}

Schaap et al. ${ }^{24}$ found circulating autoantibody to cornea in one patient with Mooren's ulcer, and Mondino et al. ${ }^{21}$ showed that 8 out of 9 patients studied had autoantibodies to cornea and conjunctiva. Mondino et al. ${ }^{25}$ demonstrated positive macrophage migration inhibition test in response to saline extract of whole human cornea, and Foster et al. ${ }^{19}$ were unable to demonstrate autoantibody to cornea or conjunctiva but noted blastogenic transformation and proliferation of lymphocytes by extracts of normal corneal stroma. Although they used both human and xenogeneic tissues in their studies, it is not clear whether both types of extract were used.

Wood and Kaufman ${ }^{28}$ and later Tabbara and Ostler ${ }^{20}$ described 2 clinical types of Mooren's ulcer: (a) Old patients with males predominant (3:2), and having no predilection for race; $25 \%$ of cases are bilateral, with moderate to severe pain, and pursue a slow and relentless course. Their prognosis is fair and they rarely perforate. $(b)$ Young patients with males predominant (3:1); blacks are frequently affected. The cases are usually bilateral $(75 \%)$, with variable amounts of pain, and have a rapid progression. The prognosis is poor; one-third perforate, and trauma is a predisposing factor.

From our case history our patient fits into category (a), and our findings in this patient are similar to those in previous studies-namely, raised serum $\operatorname{IgA}$, and the detection of autoantibody to cornea and conjunctiva. It must be stated, however, that autoantibody to cornea and conjunctiva was detected only on xenogeneic substrate (Fig. 1); we were unable to confirm this on human substrate. The 4 possibilities for this inconsistency are: (1) Rat cornea and conjunctiva as compared with human substrate may have a higher concentration of tissue-specific antigens

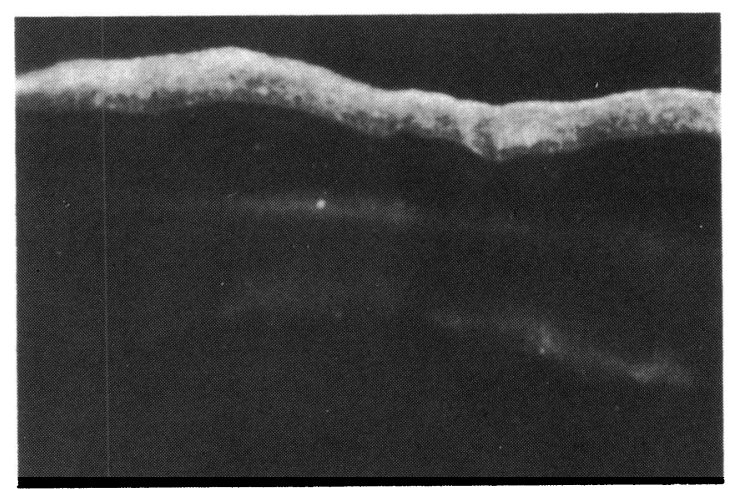

Fig. 1 Indirect immunofluorescence test showing fluorescence of rat corneal epithelium with serum from patient with Mooren's ulcer. $(\times 272)$.

which are located at more accessible positions. (2) The human substrate used was not fresh but one week old, and although it was refrigerated the possibility exists that some of the antigens might have been lost. (3) The reaction involved nonspecific antibodies cross-reacting with transplantation and other xenogeneic antigens. (4) The antibodies in the patient's serum were specific but of low affinity and therefore possibly reacted only with xenogeneic substrate.

The most significant finding (in our study) was a decrease in suppressor $T$ cells, causing an increase in the helper/suppressor ratio. This has not been reported before. The total number of E-rosetting $T$ cells, however, were within normal limits. One of the recent advances in immunology is the elucidation of a very important although complex core regulatory circuit (Fig. 2) which modulates the immune responses and regulates the biological outcome. Applying this concept to chronic inflammatory disorders of the eye we can explain most of the immunological aberrations found in Mooren's ulcer on the basis of a reduction of suppressor $\mathrm{T}$ cells as seen in the present case.

The immune system $^{29}$ is an intricate network homoeostatically balanced by positive and negative internal signals or messages passing between the different subsets of lymphocytes. These subsets differ in their surface membrane characterstics as well as their roles; some induce, others regulate, or may act as effector cells in the immune response. The current model of induction and modulation of the immune response requires recognition of antigen on the surface of the macrophage by precursors of thymusderived helper $T$ cells. The next event is the release of a soluble factor, interleukin 1 , from the macrophage, which acts on the precursor helper $T$ cell causing release of a second factor, interleukin 2 . The pre- 
Fig. 2 Core regulatory circuit of the immune response. Most of the antigens are taken up by macrophages which present them to uncommitted (pre $T_{H}$ ) helper $T$ lymphocytes, which later undergo differentiation, develop receptors for interleukin 2, and present the antigen to B lymphocytes to form plasma cells or help generate cytotoxic $\left(T_{C}\right)$ and lymphokine producing $\left(T_{D H}\right)$ lymphocytes. Paradoxically helper T cells are also involved in the maturation of suppressor $T$ cells, which in turn switch off the immune response.

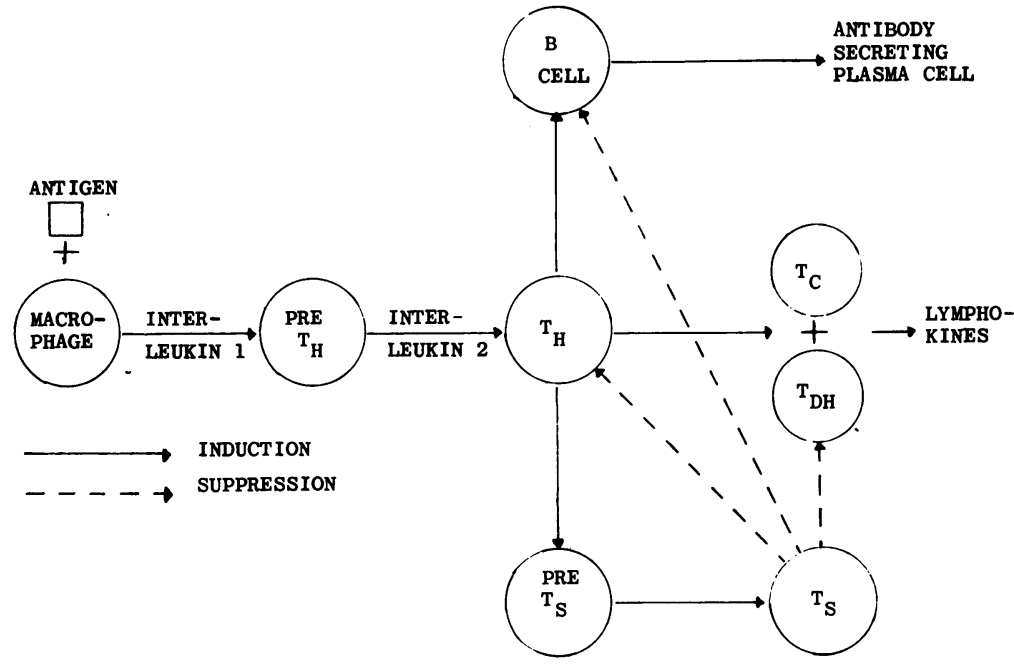

The treatment of Mooren's ulcer, either medical ${ }^{29}$ or surgical, ${ }^{30}$ is usually unsatisfactory. Possibly a new line of treatment with one of the thymic hormones may be of value in the future. Five groups of hormones have so far been isolated from or originate in the thymus. ${ }^{31}$ These are thymosin, thymopoietin, thymic humoral factor, thymostimulin, and thymic serum factor. As stated previously $\mathrm{T}$ lymphocytes differentiate and mature under the influence of the thymus, and so far thymosin has been used clinically only in diseases with low T-cell (E-rosette) levels, ${ }^{32-35}$ such as immunodeficiency states, SLE, and some types of cancer, as it has the ability to increase the number of E-rosetting cells. Ahmed et al. ${ }^{36}$ have also shown that thymosin can induce suppressor cells in vitro. Although our patient had normal E-rosetting values, it is possible that the use of thymosin in Mooren's ulcer could increase the number of suppressor cells, thereby correcting the defect in the core regulatory circuit, thus preventing further tissue damage. Another drug worth mentioning is cyclosporin A, a metabolic product of soil fungi, that has been used successfully in renal allografting. Its mode of action is unclear but it does increase the number of suppressor cells. ${ }^{37}$ Early reports of its use on patients with posterior uveitis $^{38}$ have been encouraging, though renal toxicity has not yet been excluded as few long-term studies have been carried out. They are certainly possibilities worth considering.

In conclusion, the immunological abnormalities found in Mooren's ulcer may be due to an underlying defect in the complex immune regulatory system caused by a reduction in the number of suppressor $T$ lymphocytes. In view of this finding it is tempting to speculate that a new line of treatment using thymosin or cyclosporin A may be worthwhile in this serious, sight-threatening condition. 
Our thanks are due to $\mathrm{Mr}$ Noel Rice for allowing us to publish details of this case, to Mr J. Prasad for technical assistance, and to Miss K. Betts for secretarial help. P. I. Murray is at present the recipient of the Friends of Moorfields Research Fellowship Grant.

\section{References}

1 Duke-Elder S, Leigh AG. Diseases of the outer eye: In: DukeElder S, ed. System of Ophthalmology. London: Kimpton, 1965: 8 (2): 916.

2 Frazer IH, Mackay IR. T-Lymphocyte sub-populations defined by two sets of monoclonal antibodies in chronic active hepatitis and systemic lupus erythematosus. Clin Exp Immunol 1982; 50: 107-14.

3 Strelkauskas AJ, Callery RT, McDowell J, et al. Direct evidence for loss of human suppressor cells during active autoimmune disease. Proc Natl Acad Sci USA 1978; 75: 5150-4.

4 Reinherz EL, Kung PC, Goldstein G, Schlossman SF. Separation of functional subsets of human T-cells by a monoclonal antibody. Proc Natl Acad Sci USA 1979; 76: 4061-5.

5 Reinherz EL, Schlossman SF. Regulation of the immune response-inducer and suppressor T-lymphocyte subsets in human beings. N Engl J Med 1980; 303: 370-3.

6 Wybran J, Fudenberg HH. Thymus-derived rosette forming cells in various disease states: cancer, lymphoma, bacterial and viral infections and other diseases. J Clin Invest 1973; 52: 1026-32.

7 Abdou NI, Sagawa A, Pascual E, Herbert J, Sadeghee S. Suppressor T-cell abnormality in idiopathic systemic lupus erythematosus. Clin Immunol Immunopathol 1976; 6: 192-9.

8 Reinherz EL, Weiner HL, Hauser SL, Cohen JA, Distaso JA. Schlossman SF. Loss of suppressor T-cells in active multiple sclerosis-analysis with monoclonal antibodies. $N$ Engl J Med 1980; 303: 125-9.

9 Miller AE, Hudson J, Tindall RSA. Immune regulation in myasthenia gravis: evidence for an increased suppressor T-cell population. Ann Neurol 1982; 12: 341-7.

10 Butler M, Atherton D, Levinsky RJ. Quantitative and functional deficit of suppressor T-cells in children with atopic eczema. Clin Exp Immunol 1982; 50: 92-8.

11 Char DH, Brunn J, West W. Thymus-derived lymphocytes in the Vogt-Koyanagi syndrome. Invest Ophthalmol Visual Sci 1977; 16: 179-81.

12 Heredia CD, Vich JM, Huguet J, Garcia-Calderon JV, and Garcia-Calderon PA. Altered cellular immunity and suppressor cell activity in patients with primary retinitis pigmentosa. $\mathrm{Br} \mathrm{J}$ Ophthalmol 1981; 65: 850-4.

13 Grabner G, Berger R, and Knapp W. Concanavalin A induced suppressor cell activity in inflammatory uveal disease. In: TrevorRoper P, ed. Proceedings of the 6th Congress of European Ophthalmology London: Academic Press and Royal Society of Medicine, 1980: 487-91.

14 Nussenblatt RB, Cevario SJ, and Gery I. Altered suppressor-cell activities in uveitis. Lancet 1979; ii: 601-3.

15 Nussenblatt RB, Salinas-Carmona M, Leake W, Scher I. Tlymphocyte subsets in uveitis. Am J Ophthalmol 1983; 95: 614-21.

16 Felberg N, Sergott R, Savino P, Blizzard J, Schatz N. Lymphocyte subpopulations in Graves' ophthalmopathy. Arvo Abstracts. Supplement to Invest Ophthalmol Visual Sci. St Louis: Mosby, 1983: 192.

17 Stelzer GT, Eiferman RA, Watson S. Alterations in T-cell subsets in patients with recurrent herpes simplex keratitis. Arvo Abstracts. Supplement to Invest Ophthalmol Visual Sci. St Louis: Mosby, 1983: 192.
18 Brown SI. Mooren's ulcer. Histopathology and proteolytic enzymes of adjacent conjunctiva. Br J Ophthalmol 1975; 59: 670-4.

19 Foster CS, Kenyon KR, Greiner J, Greineder DK, Friedland B, Allansmith MR. The immunopathology of Mooren's ulcer. Am J Ophthalmol 1979; 88: 149-58.

20 Tabbara KF, Ostler HB. Mooren's ulcer. In: Trevor-Roper P, ed. Proceedings of the 6th Congress of European Ophthalmology. London: Academic Press and Royal Society of Medicine, 1980: 269-73.

21 Mondino BJ, Brown SI, and Rabin BS. Autoimmune phenomena of the external eye. Ophthalmology 1978; 85: 801-17.

22 Mondino BJ. Autoimmune phenomena in ocular cicatricial pemphigoid, Mooren's ulcer and Sjögren's syndrome. In: Helmsen RJ, Suran A, Gery I, eds. Proceedings of Immunology of the Eye: Workshop: II Special Suppl Immunology Abstracts 1981: 77-89.

23 Berkowitz PJ, Arentsen JJ, Felberg NT, Laibson PR. Presence of circulating immune complexes in patients with peripheral corneal disease. Arch Ophthalmol 1983; 101: 242-5.

24 Schaap OL, Feltkamp TEW, and Breebaart AC. Circulating antibodies to corneal tissue in a patient suffering from Mooren's ulcer (ulcus rodens corneae). Clin Exp Immunol 1969; 5: 365-70.

25 Mondino $\cdot$ BJ, Brown SI, Rabin BS. Cellular immunity in Mooren's ulcer. Am J Ophthalmol 1978; 85: 788-91.

26 Brown SI. What is Mooren's ulcer? Trans Ophthalmol Soc UK 1978; 98: 390-2.

27 Cowling P, Ebringer R, Ebringer A. Association of inflammation with raised serum IgA in anklyosing spondylitis. Ann Rheum Dis 1980; 39: 545-9.

28 Wood TO, Kaufman HE. Mooren's ulcer. Am J Ophthalmol 1971; 71: 417-22.

29 Waterfield JD. New approaches to immunodeficiency in man. $J R$ Soc Med 1982; 75: 825-7.

30 Stilma JS. Conjunctival excision or lamellar scleral autograft in 38 Mooren's ulcers from Sierra Leone. Br J Ophthalmol 1983; 67: 475-8.

31 Trainin M, Pecht M. Handzel ZT. Thymic hormones: inducers and regulators of the T-cell system. Immunology Today 1983; 4: $16-21$.

32 Goldstein AL, Low TLK, Thurman GB, et al. Current status of thymosin and other hormones of the thymus gland. Recent Prog Horm Res 1981; 37: 369-412.

33 Costanzi J, Daniels J, Thurman G, Goldstein A, and Hokanson J. Clinical trials with thymosin. Ann NY Acad Sci 1979; 332: 148-59.

34 Goldstein AL, Cohen GH, Rossio JL, Thurman GB. Brown CN, Ulrich JT. Use of thymosin in the treatment of primary immunodeficiency diseases and cancer. Med Clin N Am 1976; 60: 591-607.

35 Chretien PB, Lipson SD, Makuch RW, Kenady DE. Effects of thymosin in vitro in cancer patients and correlation with clinical course after thymosin immunotherapy. Ann NY Acad Sci 1979; 332: $135-47$.

36 Ahmed A, Wong DM, Thurman GB, et al. T-lymphocyte maturation: cell surface markers and immune function induced by T-lymphocyte cell-free products and thymosin polypeptides. Ann NY Acad Sci 1979; 332: 81-94.

37 Routhier G, Epstein O, Janossy G, et al. Effects of cyclosporin A on suppressor and inducer $\mathrm{T}$ lymphocytes in primary biliary cirrhosis. Lancet 1980; ii: 1223-6.

38 Nussenblatt RB, Palestine AG, Rook AH, Scher I, Wacker WB, Gery I. Treatment of intraocular inflammatory disease with cyclosporin A. Lancet 1983; ii: 235-8. 